\title{
Understanding EU trade politics after TTIP, Trump and Brexit
}

\author{
Ferdi De Ville ${ }^{1}$
}

(C) Macmillan Publishers Ltd., part of Springer Nature 2018

\section{Straight Talk on Trade: Ideas for a Sane World Economy}

D. Rodrik

Princeton University Press, Princeton (NJ), 2017, 316p., \$29,95/£24,95, ISBN: 9780691177847

\section{The Trade Policy of the European Union}

S. Gstöhl and D. De Bièvre

Palgrave, Basingstoke, 2017, 242p., 35,99€, ISBN: 9780230271975

\section{The New Politics of Trade: Lessons from TTIP}

A. R. Young

Agenda Publishing, Newcastle upon Tyne, 2017 192p., \$25, ISBN: 9781911116752

\section{Introduction}

There are decades where nothing happens and then there are weeks where decades happen, Lenin is supposed to have said. Maybe not in a week, but certainly in a couple of them, our global economy and trade politics changed significantly. Between June and October 2016, Brexit happened, Donald Trump became elected as President of the United States (USA), a trade agreement between the European Union (EU) and Canada was almost scuppered and another transatlantic trade agreement between the EU and the US was effectively derailed.

\section{Ferdi De Ville}

Ferdi.deville@ugent.be

1 Centre for EU-Studies, Department of Political Science, Ghent University, Universiteitstraat 8, 9000 Ghent, Belgium 
Although not really the first time free trade became contested-the alter-globalisation movement caught attention in the late 1990s with successful protests against the Multilateral Agreement on Investment and against the launch of a World Trade Organisation (WTO) negotiating round in Seattle - the breadth and intensity of public debate of recent years is unprecedented. In the USA, trade was one of the most prominent themes during the 2016 Presidential election campaign. Not only Trump but also the major candidates in the Democratic Party (Hillary Clinton and, especially, Bernie Sanders) felt the need to distance themselves from one of President Obama's chief foreign policy achievements, the Trans-Pacific Partnership (TPP), a trade agreement between the USA and eleven other countries around the Pacific Rim. Although the decisive explanation for Trump's victory is still debated, convincing a couple of thousand blue collar workers in a number of Rust Belt states that had previously voted for Obama has been a key factor. His anti-trade rhetoric played a significant role in that. In Europe, tens of thousands of people participated in rallies protesting against the negotiations on a Transatlantic Trade and Investment Partnership (TTIP) between the EU and the USA. More than three million EU citizens signed a petition to ask for the termination of these negotiations. In the slipstream of the TTIP protests, the Comprehensive Economic and Trade Agreement, or CETA, between the EU and Canada came under fire and was almost defeated when the Belgian region of Wallonia refused to allow the Federal Government to sign the agreement. Also the historical decision of the United Kingdom (UK) in a referendum to leave the EU is linked to trade. As with Trump, the high majorities that voted for Brexit in the referendum in former industrial heartlands in the West Midlands is partly explained as revenge by the 'losers of globalisation'. After the referendum, establishing a new trade relationship with the EU, but also with the rest of the world, is the major challenge for the UK government.

Trade policy has become politicised. It has been dragged out of technocratic circles where only a handful of specialists mastered the discourse and details. Has the academic literature on trade policy foreseen and/or responded to this change? For long, mainstream analyses have treated trade policy as a technocratic policy domain without problematising this state of affairs. Trade policy was conceived to be about pursuing an optimal outcome (of liberalisation), which was obstructed by protectionist interest groups. Economists explained how comparative advantage makes free trade desirable while political scientists analysed how reciprocal trade liberalisation could help office-seeking politicians to overcome domestic protectionist opposition to this optimal outcome of free trade. There was hence little real 'politics', in the sense of attention for competing worldviews, ideas and objectives or power imbalances, involved in the study of trade policy. Has this changed after the politicisation of trade policy?

Three recently published books on trade policy allow us to answer this question. Each book is written by seasoned observers of trade politics. Dani Rodrik, author of Straight Talk on Trade: Ideas for a Sane Economy, is an economist who is currently Professor of International Political Economy at Harvard. He has been publishing on trade policy for over 30 years. Sieglinde Gstöhl and Dirk De Bièvre, authors of The Trade Policy of the European Union, are professors in political science at the College of Europe and the University of Antwerp, respectively, and have been writing 
on trade politics for more than 15 years. Alasdair Young, author of The New Politics of Trade: Lessons from TTIP, is Professor of International Affairs at Georgia Tech. Also his publications on trade go back to the early 2000s.

Each of the three books belongs to a different format and has its own objectives and merits. Straight Talk on Trade is a collection of essays directed to the wider public explaining why most trade policy observers and decision-makers failed to anticipate the recent contestation of the policy domain and the consequences of that. The Trade Policy of the European Union is a textbook offering a comprehensive introduction to (the study of) EU trade policy. The New Politics of Trade, finally, is a short research monograph in which the author applies his insights on trade politics to one of the controversies mentioned above, the TTIP negotiations. I will review each book in turn, then discuss how they collectively advance our knowledge and end with pointing at some research avenues they open. I start with discussing Dani Rodrik's book. It can be seen as an academic's way of saying 'I told you so!' to the rest of the world. Although especially addressing his fellow economists, the arguments about the need to change our thinking about trade policy are also very pertinent for political economists with a political science background. Then I review Gstöhl and De Bièvre's textbook, which offers a nice overview of the current political science literature on EU trade policy. In that way, it helps us check to what extent this literature already responds to Rodrik's criticisms on trade policy analyses. Finally, Young's book is a specific quest to understand and explain the new politics of trade, with TTIP as the case study.

\section{Straight talk on trade}

Dani Rodrik's book is a collection of accessible essays, which build on his extensive oeuvre on globalisation, including research on trade policy, industrialisation, development and the use of economic models. Already two decades ago, he warned in Has Globalization Gone Too Far? (Rodrik 1997) that globalisation cheerleaders, including in the economics discipline, were neglecting the fact that more globalisation is not always good, that there are always trade-offs involved, and that too much economic integration can lead to social disintegration. In 2011, he articulated this thesis even more forcefully in The Globalization Paradox: Why Global Markets, States and Democracy Can't Co-Exist (Rodrik 2011). Now, after Trump and Brexit, Rodrik is considered a visionary.

The book opens with the provocative question: 'Are economists responsible for Donald Trump's shocking victory in the US presidential election?' (p. ix). Rodrik claims that 'had economists gone public with the caveats, uncertainties, and scepticism of the seminar room, they might have become better defenders of the world economy' (p. xii). Instead, by singing the praise of globalisation, they lost credibility and left the field to populists like Trump to make a blunt attack on economic integration. The response Rodrik got from his colleagues when he warned against the costs of hyper-globalisation was that he was giving ammunition to the barbarians. In this way, the preface of the book lays out the core argument that is further developed in later chapters. The explanation for why economists unambiguously support trade 
agreements can be found in their political economy models. Their positive explanation and normative justification for trade agreements is that these allow governments to 'tie their own hands' in order to prevent that they or their successors would be captured by protectionist interest groups. This model has been developed after the Second World War with the Great Depression, exacerbated by protectionist beggarthy-neighbour policies, closely in mind. In this perspective, special interest groups of a protectionist nature are the barbarians. Free trade agreements should be wholeheartedly supported as mechanisms to weaken them.

Rodrik problematises this assumption that is still influencing thinking on trade today. Trade liberalisation has already gone so far that the aggregate gains from new trade deals have become negligible, while distributive effects have increased. Hence, there are not that many gains left that barbarians can prevent us from reaping. More importantly, in the current globalised world, the strongest 'special interest groups' in trade are no longer domestic protectionist firms (who have been weakened as a consequence of past liberalisation) but multinational corporations, who will try to capture trade policy to advance their own self-interests. By overstating the benefits of globalisation and underplaying the costs, Rodrik argues, economists 'effectively favour one set of self-interested parties- "barbarians"-over another' (p. x).

The book not only contains chapters on trade, but also on issues such as development, financial globalisation, the euro area and the economic discipline, which are less relevant for this review. The common theme throughout the book is that economists have failed to make a balanced contribution to public debate on this variety of topics. In one of the first chapters, Rodrik challenges another widely held belief in academia and politics: that the nation-state has become obsolete and that 'global governance' is both desirable and feasible. He argues that the nation-state is still the most important level at which societies are organised, and makes a normative case for this situation. As a market needs rules to function, the withering away of nationstates would mean that uniform global rules would have to be adopted. This would be undesirable as local communities have different preferences and as it would preclude experimentation with rules. Hence, the fundamental imbalance between the global nature of markets and the domestic nature of the rules that govern them, which is responsible for globalisation's current ills, cannot be corrected through global governance, but only by restricting the reach of markets. This rejection of global governance as a viable solution for the problems caused by globalisation is a necessary argument for the book's subsequent analyses and prescriptions.

In a number of chapters in the middle of the book, Rodrik gives his vision on what 'good economics' entails. The chapters provide a defence of the discipline but a rebuke to those who use it incorrectly. In a chapter on 'Economists and their models', which is based on another recent Rodrik book Economics Rules (2015), he criticises economists' interventions in public trade (and other) debates based on economic models without mentioning the (often unrealistic) assumptions behind these models or the limits of what they can forecast. This leads him to advocate for more open disagreement between economists in recognition of the diversity of economic approaches. The 'art' of good economics, Rodrik argues, is to be able to choose between different economic models on the basis of which one is best suited for a particular set of conditions. He defends a vision of academics as 'foxes', 
'scholars who are able to navigate from one explanatory framework to another as circumstances require' (p. 158), rather than 'hedgehogs', scholars who 'believe' in a single big idea. The author calls on economists to pay more attention to the role of 'ideas' besides interests to explain economic, social and political affairs. The 'rational choice political economy' model, while providing an elegant explanation for many social phenomena, includes an often-unstated assumption that all actors are self-interested and, hence, politicians are always prone to be captured by special interest groups. This cynical view on politics also leaves little room for improving matters. Rodrik calls for an introduction of ideas in political economy models that affect how actors define their preferences, constraints and policy choices. This would make economics more realistic, and able to change policy for the better, he argues. Political economy models that rely solely on 'vested interest' have a static bias: absent exogenous shocks such as revolutions or crises, changing policies is considered unlikely. But if economists allow for the role of ideas in politics, they can also conceive of their own role as 'policy innovators' in which they can successfully advocate change.

Based on his analysis of what is wrong in current academic thinking and policies on trade and related issues, in the final three chapters Rodrik looks for solutions. He starts with explaining 'What will not work'. The author dismisses the two mainstream responses to the current malaise of globalisation: compensating the losers and global governance. The idea that the backlash against globalisation can be avoided through domestic compensation of the losers by the winners of liberalisation, neglects the fact that globalisation makes it more difficult to tax the winners. Current trade agreements strengthen multinational corporations even more, without much evidence that they promote societal welfare. Rodrik cites intellectual property rights, investor rights protection and regulatory cooperation as examples. Consequently, it is necessary to also change the rules of globalisation. But global governance with homogeneous rules and policies is not the answer either, for reasons the author explained earlier.

Rodrik then proposes his solution through seven new rules for the global economy (p. 222 ff.): (1) '[m]arkets must be deeply embedded in systems of governance'; (2) '[d]emocratic governance and political communities are organised largely within nation-states, and are likely to remain so for the foreseeable future'; (3) '[t] here is no "one way" to prosperity'; (4) 'countries have the right to protect their own regulations and institutions'; (5) '[c]ountries do not have the right to impose their institutions on others'; (6) '[t]he purpose of international economic arrangements must be to lay down the traffic rules for managing the interface among national institutions'; and (7) '[n]ondemocratic countries cannot count on the same rights and privileges in the international order as democracies'. Of these, the fourth, fifth and sixth principles are most important, and most controversial. As Rodrik specifies, countries should be allowed to 'raising barriers at the border if necessary, when trade demonstrably threatens domestic practices enjoying broad popular support' ( $\mathrm{p}$. 224). Global procedural rules should ensure that trade barriers are only erected if really necessary to protect widely held domestic preferences, and without imposing preferences on other sovereign states. While differentiating measures that legitimately protect domestic preferences from those that simply protect unproductive 
firms might be difficult (cfr. Trachtman 2013), Rodrik makes a case to allow countries to take measures to avoid that trade undercuts domestic social bargains, as this is necessary to maintain public support for an open trading system.

These new rules for the global economy allow for more policy space for national governments. Rodrik then puts forward ideas for how to use this space domestically for productivity-enhancing and socially inclusive policies. The final, short chapter is called 'It's the politics, stupid!'. Here, Rodrik reminds us that globalisation is not an unstoppable force of nature but has been made by politics and is malleable by politicians. Only if mainstream politicians offer a vision of how to make globalisation more sustainable and fair will they take the wind out of the sails of extremists. 'It's the politics, stupid!' is one of the key messages of Rodrik to his fellow economists. Dani Rodrik believes that economists can learn from their colleagues in political science and sociology departments, and has himself been influenced by Karl Polanyi, John Ruggie and other constructivist social scientists. This multidisciplinary attitude makes his writings a refreshing read. It also means that his ideas about the need to rethink our understanding of trade politics are also directly relevant for political economists with a background in political science. In sum, Rodrik explains the recent politicisation of trade policy as a welcome response of civil society to the uncritical attitude of the large majority of politicians and academics towards the current free trade regime. He hopes that this will result in a re-embedding of the regime in domestic social policy choices.

\section{The trade policy of the European Union}

Gstöhl and De Bièvre rightly claim that their The Trade Policy of the European Union is 'the first real political science textbook on European trade policy' (p. xi). ${ }^{1}$ It offers an excellent introduction by discussing in a 'pluridisciplinary' way the main legal, economic, political science and international relations insights to the policy domain. The authors state that their ambition is modest, by refraining from 'the formulation of broad sweeping statements of what the EU should [or] is likely to [do] in the future' (p. 8). Rather, it wants to explain how trade policy affects interest groups that may or may not organise to influence these policies, how the EU's institutional setup makes some outcomes more likely than others and how this is all affected by international developments. As the authors write themselves, the closest they come to making their own argument in the book is that EU trade policy is prone to continuity and conservatism because it is governed by supermajorities.

The book opens with explaining why its subject is important. It starts by succinctly clarifying to the reader why countries trade in the first place. Then it explicates why the EU member states decided already in the Treaty of Rome to transfer the competence for trade policy to the supranational level. This was a

\footnotetext{
1 Alasdair Young and John Peterson's Parochial Global Europe of (2014) also covers most of the issues pertaining to the policy domain, but rather holds the middle between a research monograph and a textbook by offering a specific perspective (a 'policy subsystem approach') on the issue area.
} 
logical corollary of their decision to establish a customs union, the raison d'être of post-war European integration. A welcome side effect of the decision to supranationalise trade policy was that it strengthened the member states' position in the world trading system. Together with the USA, the EU is still the main trade power in the world. In a separate chapter, the book elaborates on the legal development of the common commercial policy. It reviews the origins of the common commercial policy and how the competence has subsequently evolved through interpretations by the Court of Justice of the European Union (CJEU) and several Treaty reforms. By discussing the consequences of the important Lisbon Treaty revisions to the common commercial policy and a recent CJEU opinion on the EU-Singapore trade agreement, readers are fully up-to-date with the legal state of affairs and its implications. In that way, this chapter also helps to understand why the wish of the UK to negotiate its own trade agreements implies that it has to leave the EU customs union, and the complications of this.

Subsequently, the authors introduce in detail EU trade policy's key (official, business and societal) players, decision-making procedures and policy instruments. They differentiate between different 'types' of EU trade policy: negotiating bilateral, regional or multilateral trade agreements, implementation of trade policy and applying unilateral trade policy measures. Very detailed descriptions of how decisions in these different trade policies are made, illustrated by accessible flowcharts and interesting case studies, which make the book also interesting for professionals working on EU trade policy. What may seem like technical details are invaluable to understanding and explaining EU trade policy. As the authors argue in the next chapter, different policy-making settings enable or constrain policy choices to different extents.

In the chapter on political economy perspectives on EU trade policy, Gstöhl and De Bièvre differentiate theories based on the level of analysis they focus on: the international system, society and the state. While theories belonging to the first category explain EU trade policy as responses to challenges and opportunities offered by the international structure, the second explains it as a function of conflict between domestic organised societal interest groups, while the latter conceives of policy-makers as largely insulated from interest groups and with some freedom to act within the international structure. The 'principle-agent' and 'two-level game' approaches are discussed as perspectives that integrate these levels of analysis in a dynamic, complex manner. These help explain the apparent contradiction that the European Commission gains bargaining power by being constrained by high voting thresholds in the Council, but more so when it holds defensive than offensive interests (hence the EU's 'conservatism bias'). The authors demonstrate the usefulness of these accounts by applying them to the EUSouth Korea Free Trade Agreement. The theories discussed are mostly rationalchoice institutionalist in nature. Interests, given by one's economic position, are supposed to inform actors' preferences and the extent to which actors are able to defend their preferences largely depends on the structure of institutions. Ideas and constructivist approaches to EU trade policy are briefly mentioned in the context of those accounts that hold that decision-makers can have autonomous trade policy preferences, and might be able to pursue them. 
The next chapter focuses on the EU in the World Trade Organization. Besides offering a crash-course into the WTO, it explains how the EU's role in the organisation gradually increased over the decades, from a defensive player in the first Round towards a co-shaper in the late 1980s and eventually the leader around the turn of the millennium. The latest 'Doha Development Round' that was mainly advocated by the EU is discussed in detail, including positions taken by the EU and the reasons for its eventual failure. The authors also explain how the EU operates in the dispute settlement mechanism of the WTO, since the failure of the Doha Round the most important function of the organisation.

The book does not contain separate chapters on bilateral and unilateral EU trade policies but instead discusses these levels in the context of chapters on trade and development and on challenges for EU trade policy, which is a choice that works well. Development has always been one of the main objectives that the EU has pursued in the policy domain, mostly through the bilateral and unilateral channels. The authors start by discussing the evolution of the EU-ACP relations. The EU's relationship with the former colonies of its member states in Africa, the Caribbean and the Pacific regions is the reason why trade and development has become one of most important intersections of the EU's external policies. Through several agreements, the EU has for decades granted unilateral market access to the ACP countries. However, after these regimes were diagnosed as a failure in promoting development, they were judged as incompatible with the EU's WTO obligations, and because developing countries in the rest of the world were gaining in importance for the EU, the Union drastically changed its trade-and-development policies in the early 2000s. Within its Generalised System of Preferences (GSP), it provides tarifffree market access to all least-developed countries ('Everything but Arms'), and it pursues bilateral trade negotiations with many other developing countries. It also increasingly tries to promote non-trade objectives like environmental and social protection through bilateral (Sustainable Development Chapters in FTAs) and unilateral trade policies ('GSP+'). The chapter also includes a brief discussion of the EU's development and humanitarian policies strictu sensu. As the authors show, 'a major challenge [...] consists in striving for policy coherence between trade and development policy' (p. 174). For example, the EU's pursuit of reciprocal liberalisation with developed economies erodes the trade preferences granted to developing countries.

The chapter on challenges for EU trade policy mainly focuses on the EU's increasing network of bilateral trade agreements. These have gained in importance after the failure of the Doha Round. But besides a higher quantity of FTAs, also their quality has changed. Taking its own integration history as an example, the EU has gained an interest in tackling 'regulatory barriers to trade', and by exerting its 'market power' aims to externalise its own internal market rules through deep and comprehensive trade agreements. Stimulated by its self-conception as a 'community of values' or a 'normative power' and by mobilisation of non-governmental organisations, the EU has also increasingly tried to use trade to promote human rights, labour and environmental standards. This poses additional challenges to guarantee policy coherence. In addition, because this expansion increases the chance that trade agreements include competences held by the Member States, and have to be ratified by them as 'mixed agreements', this can also lead to 'institutional challenges', as 
epitomised by the 'CETA saga'. Finally, Gstöhl and De Bièvre mention the rise of global value chains as bringing additional challenges to EU trade policy. They criticise FTAs as insufficiently responding to the challenge to exert public authority over multinational firms organising these value chains: 'benefits of economies of scale are likely to remain acceptable to the general public as long as public authority over multinational companies keeps pace with such development [... inter alia] in the field of taxation and international tax cooperation' (p. 202).

In the final chapter, the authors summarise their main conclusions and speculate about 'Future Prospects of EU Trade Policy'. While not the central aim of their descriptive textbook, they explain politicisation of EU trade policy, in line with the dominant rational choice institutionalist framework, as the consequence of changes to the scope of the trade agenda, the interest groups that are triggered by this, and the institutional architecture of EU trade policy. They describe how this led to 'populist' responses in some member states, how this was partly responsible for Brexit, and together with the shifting global power balances may complicate EU trade policy in the future. While not making clear predictions (as they promised not to do) of how this will change EU trade politics, they end with a positive note for EU trade policy scholars: ' $[\mathrm{t}] \mathrm{he}$ years to come are therefore bound to be very interesting times' ( $\mathrm{p}$. 211).

\section{Lessons from TTIP}

In his short book, The New Politics of Trade: Lessons from TTIP, Alasdair Young discusses one of the political shocks to the trade community discussed at the start of this essay, the failure of the TTIP negotiations, while linking this to the other surprises Trump and Brexit, which are also "manifestations of the broader anti-globalization sentiments' (p. 2). The author thereby builds on his previous work on EU trade politics and transatlantic trade relations. The title of the book echoes a special issue that he edited together with John Peterson in (2006). In their introduction to this issue, Young and Peterson had already identified how a more 'deep trade agenda' results in a 'new politics of trade'.

The book starts by explaining why the initiators of the TTIP negotiations held 'misplaced optimism' about its prospects and their ability to conclude the talks on 'one tank of gas'. The context seemed ideal for a deal. The failure of the Doha Development Round gave the EU and the USA an excuse for pursuing a bilateral agreement instead of a multilateral deal. The Great Recession and the rise of China gave them two compelling reasons to pursue a treaty. And the fact that business interests declared their unanimous support for the negotiations seemed to guarantee domestic backing. Nonetheless, this confidence turned out to be erroneous. The first chapter explains how TTIP was different from other EU trade agreements, because it involved engaging with an equal partner and focusing on regulatory barriers to trade. This lays the groundwork for explaining its eventual demise in the following chapters. It also introduces how trade agreements are negotiated and ratified on both sides of the Atlantic. These procedures, Young argues, are 'suited to simpler times': 
'the US faced particular challenges in coordinating its position, and the EU was constrained by a plethora of veto players' (p. 9).

The next chapter characterises the transatlantic economy as 'interpenetrated not integrated'. While the EU and the USA are each other's most important trading partner, especially the depth of their investment relationship stands out. Although their economic bonds are very strong, both economies should not be considered as 'integrated' as they are governed by different regulations. This increases the costs for many multinationals that do business on both sides of the Atlantic. These different regulations are the result of different political systems and regulatory cultures. In turn, the combination of transatlantic economic interpenetration but remaining regulatory divergence is crucial to understand the dynamics of the TTIP negotiations discussed in later chapters. 'TTIP's ambition in context' compares the substance of the negotiations with other EU trade agreements. While TTIP also contained traditional 'market access' elements, it stood out for the breadth of its agenda and the potential depth of its disciplines. Particularly, the attempt to eliminate regulatory differences and to establish institutions and mechanisms to avoid new divergence in the future was innovative.

Young discusses in great detail the position of business interests across the Atlantic. In contrast with traditional political economy accounts that predict conflict between import-competing and exporting firms on trade agreements, business politics looked nothing like this. Business interests were in alignment rather than in conflict on all issues on the agenda. This can be explained through three factors: because tariffs were already low before TTIP, there was little protection to lose; because two-way investment between the EU and the USA is so extensive, business associations at both sides are dominated by the same firms, who logically advocate similar positions; and the importance of global value chains means that protectionism hurts many firms involved in them. Business associations hence looked at TTIP as pursuing efficiency gains rather than exchanging market access. This unique constellation on the side of business led to the overoptimistic prediction by policy-makers that the TTIP negotiations could be concluded easily and rapidly.

However, this failed to take into account civil society organisations (CSOs), which are indeed often considered to be unimportant in trade politics. Their role is discussed in the contestation and politicisation of trade policy. Young explains CSOs' unprecedented mobilisation and its impact in three steps. The focus on 'nontariff barriers' in TTIP, which seems to result 'naturally' from the state of the transatlantic economic relationship and was supported by business, led to concerns at the side of CSOs. What business and trade officials consider a 'non-tariff barrier' is often a cherished regulation in the eyes of CSOs, which they might have fought hard for in the past (cfr. De Ville and Siles-Brügge 2017). And because the EU and the USA are economic equals, none of the two could expect to impose its rules on the other. Second, CSOs were able to frame TTIP as a threat to protection and democracy. Third, where this found a receptive ear with society, often for reasons that go beyond TTIP itself, opposition to the agreement eventually outweighed support, such as in Germany and Austria. The main frame used by critical CSOs was that TTIP undermines the regulatory autonomy of states, and thereby benefits multinationals at the detriment of civil society and democracy. This critical framing is 
different from the discourses of Bernie Sanders and Donald Trump, which are more about the economic loss of certain groups and communities due to globalisation. Therefore, Young argues that '[p]ublic opposition to TTIP [...] was constructed' (p. 91) and that ' $[\mathrm{t}]$ he different depictions of the threat from globalization [...] suggest a critical role for policy entrepreneurs in constructing public opposition to trade agreements' (p. 91).

Young then demonstrates how the deep nature of TTIP not only broadened the scope of societal actors involved, but also of official actors. At the side of the USA, this complicates the negotiating dynamics, while in the EU, it would make the ratification of an eventual deal intricate, as the CETA saga amply demonstrated. Besides societal contestation, also these institutional challenges impeded the negotiations and might have proven sufficient to make a deal impossible.

While TTIP was hence already hanging by a thread because of societal contestation and institutional complications, Brexit and Trump dealt the final 'body blows to TTIP'. Their consequences for transatlantic trade politics are discussed in the penultimate chapter. Brexit not only makes the EU less attractive to the USA, and hence leaves the latter less willing to make concessions, by taking out more then one-eight of the EU's market. With the UK, the EU also loses one of the greatest supporters of TTIP, making concessions at the side of the EU less likely. Already fraught negotiations only become more difficult. The Trump administration, furthermore, with its obsession of reducing trade deficits, its unilateral inclinations, and its unpopularity in Europe, makes TTIP even more unthinkable. Young ends, in the final chapter, with five 'lessons from TTIP' that bear relevance for future trade politics in general (p. $123 \mathrm{ff}$.): (1) the transnationalisation of production through investment and global value chains increases the importance of behind-the-border measures; (2) this increases support for trade liberalisation among firms; (3) but it leads to more opposition on the side of civil society, making trade policy more controversial and administratively complicated; (4) regulatory cooperation can also occur outside of trade agreements, and this may be easier; (5) and concluding deep trade agreements with multiple players might be difficult.

\section{When read together}

Collectively, the three books offer a very comprehensive overview of EU trade policy, its current challenges, and controversies. Rodrik explains what is behind these challenges and controversies (the too long neglected risk that trade agreements can strengthen multinational companies over governments and civil society, and economic over other considerations), why many failed to foresee them and what to do about it. Gstöhl and De Bièvre introduce the reader to all the dimensions of the policy area in the EU, and to the mainstream thinking on the subject. They show how traditional political economy models, combining interests, institutions, and the international system, help explain many positions the EU adopts in trade policy, and why an expanding agenda challenges its legitimacy, effectiveness, and coherence. Young applies these insights to the failure of the TTIP negotiations. He shows how, in the context of changes to the 
international economy, negotiations between two equals that focus on eliminating regulatory differences result in a different conflict constellation than was previously the case. Instead of a struggle between import-competing and exporting firms, business interests tend to align and civil society organisations, which fear that protection will be sacrificed at the altar of economic integration, appear in the arena as their opponents. They bring normative arguments to the battlefield, stimulating more constructivist analyses of trade politics. While Rodrik normatively argues that politicisation may change trade politics for the better through a more balanced representation of actors and considerations, Gstöhl and De Bièvre and Young note in a more detached way that this complicates trade politics.

Young argued that decision-making procedures in trade in the EU and the USA were 'suited for simpler times' (p. 7). I believe these books, and Rodrik's in particular, show that the same can be said for the old rational-choice explanations of trade policy. The policy domain can no longer be satisfactorily modelled as simply a function of conflict between two economic interest groups, exporting and import-competing firms, where trade agreements provide office-seeking politicians with the instruments to overcome protectionist opposition to the supposedly optimal outcome of free trade. As the books by Gstöhl and De Bièvre and Young show, political scientists have already began to adapt their models, by bringing in new economic interest groups (such as importers and retailers) as well as civil society organisations and giving somewhat greater weight to the role of ideas besides interests and institutions. They thereby answer to Rodrik's plea for social scientists to be academic foxes.

However, in line with Rodrik's additional criticism on trade policy and how it is studied, we could argue that political scientists could do more. Rodrik argues that current trade agreements, rather than generating welfare improvements, result primarily in income and power redistribution and may as a consequence undermine domestic social bargains. Political science analyses of trade policy could help study if and how multinational companies actively capture trade agreements to promote their interests or how trade liberalisation structurally increases their market power, and how this affects domestic political outcomes. This includes constructivist analyses of how the rhetoric about regulations as 'non-tariff barriers' affects domestic regulatory politics (cfr. De Ville 2011). This might sound as unattractively normative scholarship to some. But as Robert Cox stated, research 'is always for someone and for some purpose' (1981: 129). Rodrik has convincingly shown that traditional political economy accounts of trade policy implicitly support economic integration and those who benefit from it. Scholars using them are also normative often without realising it. While this stance might have been laudable in the period after the Second World War with 1930s beggar-thyneighbour policies fresh in mind, today, as Gstöhl and De Bièvre recognise, the challenge to which we may wish to contribute is to restore public authority over multinational companies. If we as analysts don't bring in real politics in trade policy, we again leave the field to the likes of Trump to do that for us. 


\section{References}

Cox, R.W. 1981. Social forces, states and world orders: Beyond international relations theory. Millennium 10(2): 126-155.

De Ville, F., and G. Siles-Brügge. 2017. Why TTIP is a game-changer and its critics have a point. Journal of European Public Policy 24(10): 1491-1505.

De Ville, F. 2011. European Union regulatory politics in the shadow of the WTO: WTO rules as frame of reference and rhetorical device. Journal of European Public Policy 19(5): 700-718.

Rodrik, D. 1997. Has globalization gone too far. Washington, DC: Institute for International Economics.

Rodrik, D. 2011. The globalization paradox: Why global markets, states, and democracy can't coexist. Oxford: Oxford University Press.

Rodrik, D. 2015. Economics rules: The rights and wrongs of the dismal science. New York City: WW Norton \& Company.

Trachtman, J.P. 2013. Review essay: The antiglobalisation paradox-freedom to enter into binding international law is real freedom. The World Economy 36(11): 1442-1454.

Young, A.R., and J. Peterson. 2006. The EU and the new trade politics. Journal of European Public Policy 13(6): 795-814.

Young, A.R., and J. Peterson. 2014. Parochial global Europe: 21st century trade politics. Oxford: Oxford University Press.

Ferdi De Ville is assistant professor in EU politics at the Department of Political Science, Ghent University. His research and teaching focuses on European political economy and EU trade policy in particular. He has published widely on these subjects and is the author (with Gabriel Siles-Brügge) of 'TTIP: The Truth about the Transatlantic Trade and Investment Partnership' (Polity Press). 